\title{
The Establishment of Vegetable and Fruit Markets and Nurseries: A Case Study in the Waterberg District, Limpopo Province, South Africa
}

\author{
P. Maponya ${ }^{1}$, D. Modise ${ }^{1}$, E. Van Den Heever ${ }^{1}$, S. Mahlangu ${ }^{1}$, N. Baloyi ${ }^{1}$, A. Maluleke $^{1}$, D. Chauke ${ }^{2}$, \\ R. Mkhari ${ }^{2}$, J. Carstens ${ }^{3}$, M. Van Der Walt ${ }^{3}$, L. Sole ${ }^{4}$, M. Duba ${ }^{4}$, J. Malebana ${ }^{5} \&$ M. Mphahlele ${ }^{6}$ \\ ${ }^{1}$ Agricultural Research Council - Vegetable and Ornamental Plant Institute, Pretoria, South Africa \\ ${ }^{2}$ Department of Rural Development and Land Reform, Polokwane, South Africa \\ ${ }^{3}$ Agricultural Research Council - Institute for Soil, Climate and Water, Pretoria, South Africa \\ ${ }^{4}$ Waterberg District Municipality, Modimolle, South Africa \\ ${ }^{5}$ Department of Agriculture, Forestry and Fisheries, Modimolle, South Africa \\ ${ }^{6}$ Department of Rural Development and Land Reform, Pretoria, South Africa \\ Correspondance: P. Maponya, Agricultural Research Council - Vegetable and Ornamental Plant Institute, \\ Pretoria, South Africa. E-mail: maponyap@arc.agric.za, phokelemaponya@gmail.com
}

Received: March 14, 2014 Accepted: April 11, 2014 Online Published: June 15, 2014

doi:10.5539/jas.v6n7p38 URL: http://dx.doi.org/10.5539/jas.v6n7p38

\begin{abstract}
This paper highlighted the importance of the establishment of vegetable and fruit markets and nurseries in the Waterberg District, Limpopo Province, South Africa. This was achieved by taking a representative sample consisting of 57 agricultural projects, with 792 beneficiaries participating in this research. The following six local municipalities were visited: Lephalale, Thabazimbi, Mookgopong, Mogalakwena, Modimolle and Bela-Bela. Quantitative and qualitative methods were used including a detailed questionnaire written in English, focus group discussions, stakeholder's discussions, and field observations as part of the data collection. A purposive sampling technique was used to select 57 projects, in order to cover uniformity and homogenous characteristics such as infrastructure requirements, skills availability, production challenges, agricultural training needs, water source needs, and educational level. Data was coded, captured, and analysed with a software package for social sciences (SPSS version 20) using Descriptive Analysis and Univariate Regression Analysis. The results showed a significant association among the following variables: age, educational level, farming experience, land, land acquisition, crop planted, water source, water rights, agricultural training and market participation. It is recommended that fruit and vegetable markets be established, as well as the creation of a complete, viable agro value chain that will expand community driven agricultural production and processing.
\end{abstract}

Keywords: Waterberg District, Limpopo Province, South Africa, vegetable markets, fruit markets, agricultural projects and agricultural production

\section{Introduction}

Agriculture is the main vehicle for overall economic growth and poverty reduction in many developing countries, including South Africa. According to the Food and Agriculture Organization (FAO, 2012) agricultural projects are undertaken in the context of the much broader goal of rural community development, i.e. addressing the non-farm rural economy, environmental sustainability, infrastructure, financial and social services for the poor rural population. Investment in the agriculture sector is clearly one that has undeniable potential to make enormous impact on the livelihoods of people to, alleviate poverty and bring security and nutritional balance to name a few (Osci-Bimpch, 2013). With a large percentage of rural population in the Waterberg district depending on agriculture for their livelihoods, it is critical for different stakeholders involved in the food economy to examine, question and engage in the establishment of sustainable village based markets, fruits and vegetable nurseries.

According to (StatsSA, 2011) agriculture in the Waterberg district, Limpopo Province is seen as a key catalyst for significant economic development. The Waterberg district is suitable for livestock production and crop production, with the major crops produced being cotton, sunflower, tobacco, and soya bean. The current agricultural situation in the Waterberg district was further provided by Waterberg District Municipality [WDM] 
(2013). Lephalale local municipality is seen as an area with high agricultural potential. A number of labour intensive development initiatives have been identified as having the potential for ensuring wide-spread economic spin-offs for local communities. The Mogalakwena local municipality, unlike Lephalale, has a smaller agricultural sector. Its potential centers mainly on the production of crops and meat for regional consumption. The Mookgophong local municipality agricultural activity is, in no small part, responsible for this economic development. A number of opportunities have been identified in the agricultural sector, although the local economic development refers to only a few agriculturally related activities. Bela-Bela local municipality contributes about $7 \%$ of the Waterberg district, with some agricultural projects having been established in the last few years. Presently agricultural development has certain development potential in this local municipality. Thabazimbi local municipality contributes $40 \%$ of the district's agricultural activity, and the sector employs $22 \%$ of the labour in the area. Although mining and agriculture are the dominant sectors, cultivation of fruits and vegetables is generally on the decline. The exception to this trend is hunting and eco-tourism. In Modimolle local municipality agriculture contributes roughly $18 \%$ of the Waterberg district economic activities.

The Agricultural research Council (ARC) is currently involved in an agricultural project in the Waterberg district as well as in other districts in the Limpopo province where beneficiaries will be trained and mentored so as to implement sustainable production and develop markets. In the present study research was conducted with the overall aim of establishing if sustainable agricultural markets are viable in the Waterberg district. The major objectives were: (1) To identify and describe the characteristics of selected agricultural projects in the Waterberg district. (2) To determine factors that influence decision making to participate in agricultural markets.

\section{Methodology}

Quantitative and qualitative methods were used. A detailed questionnaire written in English was developed for the data collection. The questionnaire used both open and closed ended questions. Focus group discussions and field observations were also part of the data collection. As part of standard protocol for conducting the study, meeting was held with all stakeholders in the Waterberg district namely: (1) local municipalities, (2) Department of Agriculture, Forestry and Fisheries (DAFF), (3) Department of Rural Development and Land Reform (DRDLR), (4) local economic agencies and (5) local farmers. The aim of the meeting was to introduce and explain the aim of the study, and future plans of the potential market.

A purposive sampling technique was used to select 57 agricultural projects (Table 2). The sampling was used to assess uniformity and homogenous characteristics like infrastructure needs, skills availability, production challenges, agricultural training needs, and water source needs, educational level, land acquisition, size of land farming experience, source of water, inputs and implements used (Table 1). Agricultural projects visited in the Waterberg district were prioritised based on the agriculture potential of the area namely project type, numbers of projects around an area, size of the land, chances of extending production, water availability, commitment of members to their projects, internal conflicts and working material and infrastructure.

Table 1. Definition of variables included in the Model

\begin{tabular}{ll}
\hline Variables & Description of variables \\
\hline Age & Age of the respondent/ farmer \\
Gender & The gender of the respondent \\
Educational Level & The highest educational level that a respondent possesses \\
Land acquisition & The form in which the farm was acquired or purchased \\
Size of the land farmed & The size of the farm which is under crop production \\
Number of years in farming & Farming experience of the respondent(s) \\
Soil sample & If whether the soils of the farm have been tested \\
Crop planted & Type of crops that they produce \\
Inputs available & Inputs that they use for production activities \\
Implements used & Implements that are used for production operation \\
Source of water for irrigation & Where the respondent get water for irrigation of their farms \\
\hline
\end{tabular}


Table 2. Agricultural projects visited in the Waterberg district, Limpopo Province

\begin{tabular}{lll}
\hline Number of projects per local municipality & Number of projects & $\%$ \\
\hline Lephalale & 16 & 28.1 \\
Modimolle & 7 & 12.3 \\
Thabazimbi & 9 & 15.8 \\
Mookgopong & 9 & 15.8 \\
Mogalakwena & 7 & 12.3 \\
Bela-Bela & 9 & 15.8 \\
Total & 57 & 100 \\
\hline
\end{tabular}

The Limpopo Province lies in the northern part of South Africa, and has shared borders with Zimbabwe and Botswana, which allows favourably economic cooperation with these countries (StatsSA, 2011). It has a total number of 5 district municipalities, namely: Waterberg, Capricorn, Sekhukhune, Mopani and Vhembe (StatsSA, 2011).

The study was conducted in the Waterberg district, with the following six local municipalities visited as indicated in Figure 1: Lephalale, Thabazimbi, Mookgopong, Mogalakwena, Modimolle and Bela-Bela. The annual rainfall of the Waterberg district varies between $600-700 \mathrm{~mm}$. According to Carstens and van der Walt (2013) the Waterberg district has some low to moderately suitable arable areas for rainfed agriculture, where slope and soils permit.

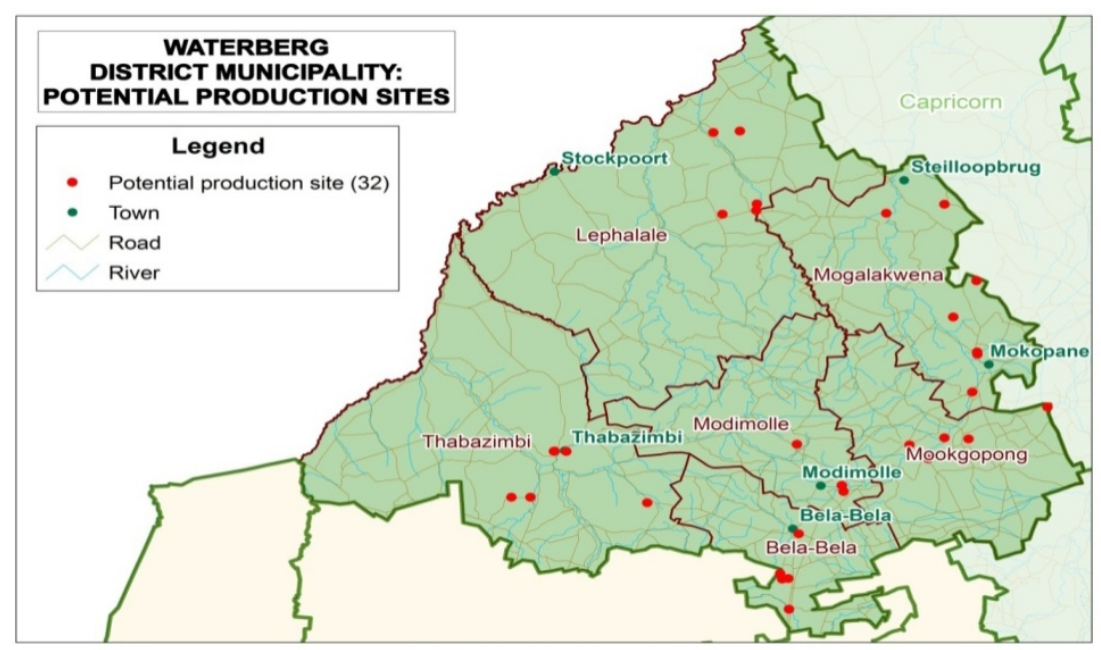

Figure 1. Map of Waterberg District indicating selected potential production sites (shown as red dots)

Data was captured and analysed using the software package for social sciences (SPSS version 20). Descriptive Analysis was used to describe data and Univariate Regression Analysis was conducted to demonstrate the relationship and association of variables. The following econometric model was used to determine association of variables (Mozza Bauzza et al., 2005):

$$
\mathrm{Wi}={ }_{-}+\mathrm{Xi}_{+} \mathrm{i}
$$

$\mathrm{Wi}$ is the dependent variable value for person $\mathrm{i}$

$\mathrm{Xi}$ is the independent variable value for person $\mathrm{i}$

$$
\begin{gathered}
-{ }^{\text {and }} \text { _ are parameter values } \\
\mathrm{i} \text { is the random error term }
\end{gathered}
$$

The parameter_is called the intercept or the value of $\mathrm{W}$ when $\mathrm{X}=0$

The parameter _ is called the slope or the change in $\mathrm{W}$ when $\mathrm{X}$ increases by one 


\section{Results and Discussion}

\subsection{Socio-Economic Factors}

The projects had a total number of 792 beneficiaries, with most beneficiaries (67\%) in the Mogalakwena municipality. Most project respondents fell into the $46-60$ years age group, but there was also a good representation from other age categories. It was evident that all age categories have an interest in agriculture; hence the training in sustainable production and establishment of agricultural markets, nurseries and agro processing plants should be supported by the identified projects in the Waterberg district.

The majority of respondents had completed secondary education (63.2\%), 22.8\% had completed primary education and $1.8 \%$ had no schooling. Only a few respondents $(7 \%)$ had post-secondary education. According to Anley et al. (2007) improving education and employment is a key requirement to stimulate local participation in agricultural production and natural resource management initiatives. It was further emphasised by Maddison (2007) that educated and experienced farmers possess more knowledge and information about agricultural production activities. The socio economic factors of beneficiaries are indicated in Table 3 .

Table 3. Socio-economic factors of Beneficiaries

\begin{tabular}{lcc}
\hline & Number of beneficiaries & \% \\
\hline Local municipality & 13 & 1.6 \\
Lephalale & 49 & 6.2 \\
Modimolle & 42 & 5.3 \\
Thabazimbi & 86 & 11 \\
Mookgopong & 529 & 67 \\
Mogalakwena & 73 & 9.2 \\
BelaBela & & \\
Age (Years) & 12 & 21.1 \\
$\mathbf{1 8}-\mathbf{3 5}$ & 10 & 17.5 \\
$\mathbf{3 6}-\mathbf{4 5}$ & 26 & 45.6 \\
$\mathbf{4 6}-\mathbf{6 0}$ & 9 & 15.8 \\
$\mathbf{6 0}>$ & & \\
Education level & 1 & 1.8 \\
No Schooling & 13 & 22.8 \\
Primary education completed & 36 & 63.2 \\
Secondary education complete & 7 & 12.3 \\
Post-secondary education completed (tertiary) & & \\
\hline
\end{tabular}

\subsection{Production Analysis}

In terms of land acquisition, own finance (28.1 percent), land redistribution for agricultural development (29.8\%) and permission to occupy $(12.3 \%$ ) remains the most popular (Table 4 ), with $8 \%$ of the land system being rented. Table 4 indicate that only a few projects acquired land through lease, municipal, tribal, project, mine and trusts.

Table 4. Types of land acquisition

\begin{tabular}{lcc}
\hline Land acquisition & Number of projects & \% \\
\hline Own finance & 16 & 28.1 \\
Land redistribution - agricultural development & 17 & 29.8 \\
Permission to occupy & 7 & 12.3 \\
Lease & 2 & 3.5 \\
Municipal & 3 & 5.3 \\
Tribal land & 4 & 7 \\
Project land & 4 & 7 \\
Mine land & 2 & 3.5 \\
Trust land & 2 & 3.5 \\
Total & 57 & 100 \\
\hline
\end{tabular}


Most of the respondents, farm on land which is $1-5$ hectare in size (36.8 \%), while only $14 \%, 8.8 \%$ and $12.3 \%$ of projects were $6-10,11-20$ and $21-50$ hectares in size respectively (Table 5). A number of projects had land of $>51$ ha $(28.1 \%)$.

Table 5. Size of land farmed

\begin{tabular}{lll}
\hline Size (ha) & Number of projects & \% \\
\hline $\mathbf{1 - 5}$ & 21 & 36.8 \\
$\mathbf{6 - 1 0}$ & 8 & 14 \\
$\mathbf{1 1 - 2 0}$ & 5 & 8.8 \\
$\mathbf{2 1}-\mathbf{5 0}$ & 7 & 12.3 \\
$>\mathbf{5 1}$ & 16 & 28.1 \\
Total & 57 & 100 \\
\hline
\end{tabular}

The results show projects variation in terms of farming experience acquired over time (Table 6). Almost $91.2 \%$ of projects beneficiaries had $1-20$ years in farming, while $7 \%$ had $21-49$ years in farming, and 1.8 percent had 50> years in farming.

Table 6. Number of years of beneficiaries involved in farming

\begin{tabular}{lll}
\hline Years & Number of projects & $\mathbf{\%}$ \\
\hline $\mathbf{1 - 5}$ & 24 & 42.1 \\
$\mathbf{6 - 1 0}$ & 19 & 33.3 \\
$\mathbf{1 1 - 2 0}$ & 9 & 15.8 \\
$\mathbf{2 1}-\mathbf{4 9}$ & 4 & 7 \\
$>\mathbf{5 1}$ & 1 & 1.8 \\
Total & 57 & 100 \\
\hline
\end{tabular}

As shown in Figure 2,79 \% of projects respondents had received agricultural training before the start of the current study. Most of the respondents agreed that government departments, local economic development agencies, non-governmental organizations, local municipalities and private companies were playing a vital role in terms of training. As indicated in Table 7, the current project provided training in vegetable production to beneficiaries.

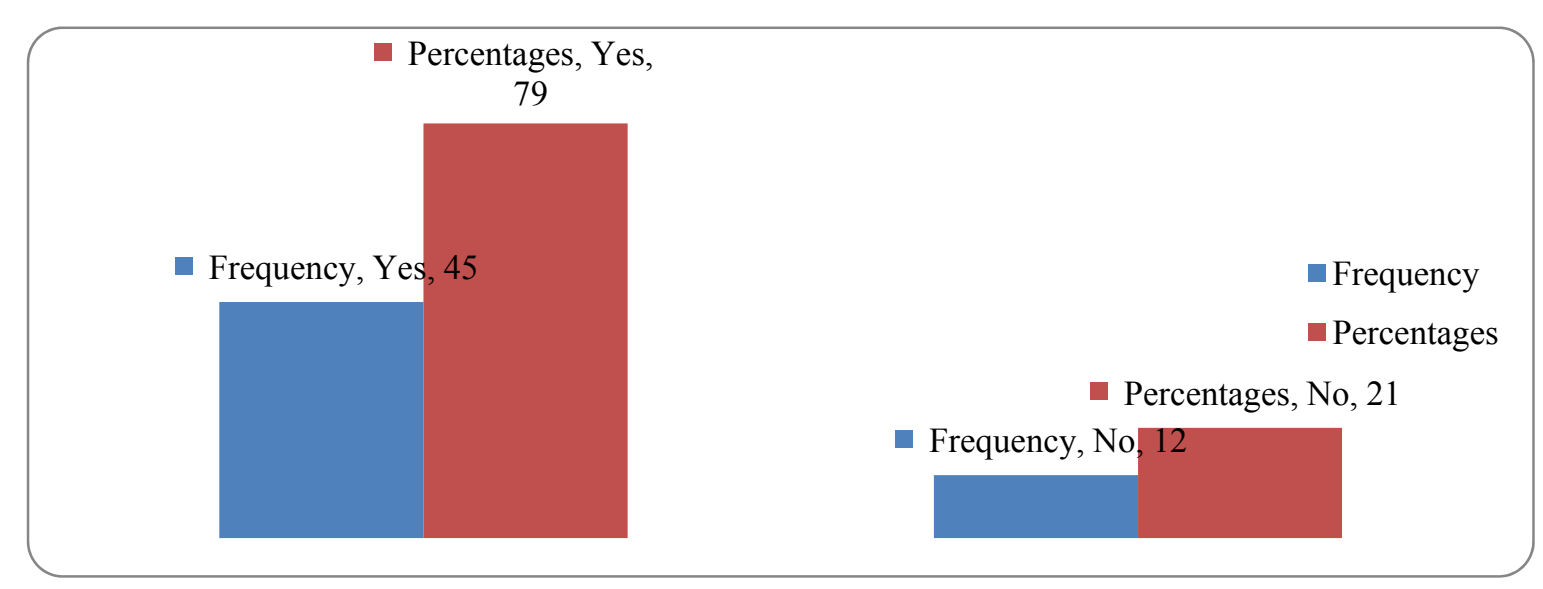

Figure 2. Agricultural training of respondents 
Agricultural training for beneficiaries was also conducted in the present project in the Waterberg district. As indicated in Table 7, training was clustered at Lephalale \& Thabazimbi, Modimolle \& Bela-Bela, and Mookgopong \& Mogalakwena. According to Table 7 the Thabazimbi \& Lephalale cluster had the most beneficiaries (50) compared to the other clusters (both 40). Studies on the benefits of investment in higher education in Africa have found rates of return on investment of $14 \%$ at the social level and $33 \%$ at the private or individual level (UNESCO, 1995). Non-formal education can have equally impressive results. A 1992 study on the value of education for small-scale farmers in Nigeria found that an increase in the average education of a farmer by one year increases the value added to agricultural production by $24 \%$ (cited by UNESCO, 1995). The same study concluded that "investment in farmer's education or a successful policy of bringing educated persons into agriculture can accelerate agricultural production."

Table 7. Training of beneficiaries per cluster

\begin{tabular}{lll}
\hline Municipalities & Number of projects & $\mathbf{\%}$ \\
\hline Lephalale \& Thabazimbi & 50 & 38 \\
Modimolle \& Bela Bela & 40 & 31 \\
Mookgopong \& Mogalakwena & 40 & 31 \\
Total & 130 & 100 \\
\hline
\end{tabular}

Of the projects visited, $57.9 \%$ have conducted soil testing while $42.1 \%$ of projects still have to conduct soil sampling. The percentage of farmers of which their soils were not tested raised concerns and need immediate attention. Testing of soils and the application of required lime and fertilizer is important for good crop production.

Table 8. Testing of soils by beneficiaries

\begin{tabular}{lll}
\hline & Number of projects & $\mathbf{\%}$ \\
\hline Yes & 33 & 57.9 \\
No & 24 & 42.1 \\
Total & 57 & 100 \\
\hline
\end{tabular}

Table 9 showed that $57.9 \%$ of projects produce vegetables, $12.3 \%$ produce grain and vegetables, and $14 \%$ produce vegetables and citrus. Very few projects produced a combination of fruits and vegetables. This information is very important, as it gives an indication of how many projects will support the markets and nurseries to be established by the project.

Table 9. Crops planted

\begin{tabular}{lll}
\hline Crops & Number of projects & $\mathbf{\%}$ \\
\hline Vegetables & 33 & 57.9 \\
Grain, vegetables, citrus & 1 & 1.8 \\
Grain, vegetables & 7 & 12.3 \\
Vegetables, citrus, deciduous & 2 & 3.5 \\
Vegetables, citrus & 8 & 14 \\
Vegetables, deciduous & 3 & 5.3 \\
Citrus, deciduous & 1 & 1.8 \\
Not applicable & 2 & 3.5 \\
Total & 57 & 100 \\
\hline
\end{tabular}


Table 10 shows that projects in the Waterberg district used different types of agricultural supplies inputs. Results indicated that $49.1 \%$ of projects had access to seeds, kraal manure, fertilizer and pesticides, with only few projects had access to a combination of inputs. According to Harvey (2012), efficient use of farm inputs - including fertilisers, crop protection chemicals, seeds and fuel - is essential in ensuring profitability, driving productivity growth and improving environmental sustainability of farm businesses.

Table 10. Agricultural supplies available

\begin{tabular}{lll}
\hline Production Inputs & Number of projects & $\mathbf{\%}$ \\
\hline Seeds & 3 & 5.3 \\
Kraal manure & 1 & 1.8 \\
Fertiliser & 2 & 3.5 \\
Pesticides & 1 & 1.8 \\
Kraal manure, fertiliser, pesticides & 3 & 5.3 \\
Seeds, kraal manure, fertiliser, pesticides & 28 & 49.1 \\
Kraal manure, fertiliser, pesticides, & 3 & 5.3 \\
Seedlings & & \\
Seeds, fertiliser, pesticides & 9 & 15.8 \\
Fertiliser, pesticides & 5 & 8.8 \\
Seeds, fertiliser, pesticides, chicken Manure & 1 & 1.8 \\
Not applicable & 1 & 1.8 \\
Total & 57 & 100 \\
\hline
\end{tabular}

Table 11 shows that $60 \%$ of the projects had access to hand-tools, and few projects having access to a combination of implements. The high costs of hiring tractors remain an obstacle to production. According to FAO (2012) farm-raised crops and livestock are the major source of food for people. In order to grow crops and raise animals on the farm, implements play an important role.

Table 11. Implements used

\begin{tabular}{|c|c|c|}
\hline Implements & Number of projects & $\%$ \\
\hline Tractor & 3 & 5.3 \\
\hline Tractor, planter, boom spray & 3 & 1.8 \\
\hline Tractor, plough, hand tools, Sprayer & 6 & 3.5 \\
\hline $\begin{array}{l}\text { Tractor, planter, ripper, plough, sprayer/ } \\
\text { pivot }\end{array}$ & 8 & 1.8 \\
\hline $\begin{array}{l}\text { Spades, wheelbarrow, dripper system, net } \\
\text { houses }\end{array}$ & 1 & 5.3 \\
\hline Hand tools & 34 & 49.1 \\
\hline All implements & 1 & 5.3 \\
\hline Not applicable & 1 & 15.8 \\
\hline Total & 57 & 100 \\
\hline
\end{tabular}

Agriculture requires large quantities of good quality of water for use in various production processes. According to FAO (2012) irrigation uses up to $70 \%$ of all fresh water appropriated for human use. In the Waterberg district farmers used different water sources for irrigation (Table 12), with $75.4 \%$ of projects using borehole water, $8.8 \%$ of projects using dam water and $1.8 \%$ of projects using river water. Few projects had access to a combination of water sources. 
Table 12. Sources of water used for irrigation

\begin{tabular}{lcc}
\hline Water Source & Number of projects & \% \\
\hline Dam & 5 & 8.8 \\
River & 1 & 1.8 \\
Borehole & 43 & 75.4 \\
Borehole, river & 3 & 5.3 \\
Dam, borehole & 2 & 3.5 \\
Not applicable & 3 & 5.3 \\
Total & 57 & 100 \\
\hline
\end{tabular}

Table 13 confirmed the need for the establishment of agricultural markets in the Waterberg district. As indicated in Table $13,40.4 \%$ of projects recognised the lack of markets as the $1^{\text {st }}$ most challenge, $24.6 \%$ of projects recognised the lack of markets as the $2^{\text {nd }}$ most challenging stage as compared to $8.8 \%$ of projects who recognised lack of markets as a least production stage. The results presented in Table 13 shows that almost $65 \%$ of projects have serious challenges in terms of markets if the levels of challenging are combined.

Table 13. Lack of markets

\begin{tabular}{lll}
\hline Source & Number of projects & $\mathbf{\%}$ \\
\hline $\mathbf{1}^{\text {st }}$ challenging production stage & 23 & 40.4 \\
$\mathbf{2}^{\text {na }}$ challenging production stage & 14 & 24.6 \\
$\mathbf{3}^{\text {ra }}$ challenging production stage & 5 & 8.8 \\
$\mathbf{4}^{\text {th }}$ challenging production stage & 7 & 12.3 \\
$\mathbf{5}^{\text {th }}$ challenging production stage & 1 & 1.8 \\
$\mathbf{6}^{\text {th }}$ challenging production stage & 2 & 3.5 \\
$7^{\text {th }}$ challenging production stage & 5 & 8.8 \\
Total & 57 & 100 \\
\hline
\end{tabular}

Lack of knowledge and agricultural inputs are the major causes of poor production leading to struggles in accessing markets (Table 14). Results showed that $31.6 \%$ of projects had no knowledge and inputs to be able to produce for formal markets, and explained why projects beneficiaries need agricultural training before the establishment of markets. Only a few projects recognised a combination of lack of knowledge, inputs, workers and budget as causal factors. Again internal group conflicts is not really a causal factor as seen in Table 14 because we only identified agricultural projects that have little/no conflicts in their operations.

Table 14. Lack of market causal factors

\begin{tabular}{lll}
\hline Causal factors & Number of projects & \% \\
\hline Lack of Knowledge & 3 & 5.3 \\
Lack of Inputs & 8 & 14.0 \\
Lack of Knowledge, Inputs & 18 & 31.6 \\
Lack of Knowledge, Inputs, Workers & 8 & 14.0 \\
Lack of Inputs, Workers & 7 & 12.3 \\
Lack of Knowledge, Inputs, Workers and & 4 & 7 \\
Group Conflicts & 1 & \\
Internal Group Conflicts & 2 & 1.8 \\
Budget & 3 & 3.5 \\
Lack of Knowledge, Workers & 2 & 5.3 \\
Lack of Knowledge, Internal Conflicts & 1 & 3.5 \\
Lack of Inputs, Internal Conflicts & 57 & 1.8 \\
Total & & 100 \\
\hline
\end{tabular}




\subsection{Regression Analysis}

As shown in Table 15, there is an association among the following variables: age, farming experience, education level, land acquisition, land size, crops planted, water source and agricultural training. This is supported by the fact that their estimate values are more than 1 at the $95 \%$ confidence interval. The odds of age to participate in agricultural markets were 1.00 , which indicated a positive association among age and market participation. This implies that any age category can participate and sell their produce to markets, and also indicates that older and younger generations can learn from each other's experience to participate in markets. According to Makhura (2001) age is positively associated with participation in agricultural markets, since older farmers may be more experienced in marketing management, having stronger networks and more credibility, which they can pass on to younger farmers. It is also not surprising that there is a positive association between age, farming experience and market participation, because according to Van Rooyen, Vink and Christodoulou (1987) the age of farmers normally provides a proxy for experience in farming, thus increasing market participation.

The odds of farmer's education level to increase market participation are 1.10. Again these results show a positive association between education level and market participation, and also show a positive association among agricultural training, farming experience and market participation. This indicates that farmers with good education levels/training/experience are able to interpret information better and invest in market activities. According to Makhura (2001) education/experience/training allows farmers to interpret information about the market. It can be concluded that better education of farmers increases their chances to participate in the market.

Land acquisition is positively associated with market participation. The odds of land acquisition to market participation are 1.00. Access to arable land and water sources remain essential for market participation before the establishment of fruit and vegetable markets. Thus the association between land, water sources and market participation remained positive.

Land size is also positively associated to market participation. This was confirmed by Mathye, Makhura and Kirsten (2000) who emphasized that the size of the farm (land) used for production is positively related to market participation. When farmers have more land, their production will be higher.

The odds of crops planted to market participation is 1.12 , which clearly indicates a positive association among market participation, age, land acquired, size of land, and water source. According to Maponya \& Moja (2012) age, access to water source and land (of any size) increases the chances of farmers and housholds to sell produce to the markets. These results were also confirmed by other researchers (Van Rooyen et al., 1987; Mathye et al., 2000; Makhura, 2001; Makhura \& Mokoena, 2003) that more access to arable land increases the chance of selling horticultural crops significantly, given availability of water sources. The authors further emphasised that age is also important in the decision to sell horticultural crops, which is again based on farming experience.

Table 15. Univariate Regression Analysis of market participation

\begin{tabular}{llll}
\hline Variable & Total & $\mathbf{\%}$ & OR [95\%CI] \\
\hline Age & 57 & 100 & $1.00[0.158-5.441] 1$ \\
Education Level & 57 & 100 & $1.10[0.575-4.999] 1$ \\
Farming Experience & 57 & 100 & $1.20[0.126-10.999] 1$ \\
Land Acquisition & 57 & 100 & $1.00[0.127-2.112] 1$ \\
Land Size & 57 & 100 & $1.01[0.76-3.555] 1$ \\
Crops Planted & 57 & 100 & $1.12[0.376-2.566] 1$ \\
Water Source & 57 & 100 & $1.10[0.50-3.011] 1$ \\
Agricultural Training & 57 & 100 & $1.04[0.35-3.456] 1$ \\
\hline
\end{tabular}

$\mathrm{OR}=$ Odds ratio $; 95 \% \mathrm{CI}=95 \%$ confidence intervals; $1<=$ no association; $1>=$ association.

\section{Summary and Conclusion}

The research indicated that there is a positive association among age, farming experience, education level, land acquisition, land size, crops planted, water source and agricultural training. It is also evident that some of these farmers are generally poor and contribute inadequately to the mainstream markets, because of low production and poor access to other livelihood options. Studies have shown that when poor farmers participate in the market, it promotes sustainable development, for instance some emerging farmers have become more 
commercial as a result of access to markets (reference/s to studies). Therefore the establishment of agricultural markets in the Waterberg district will promote sustainable development and should be considered as a priority by all stakeholders involved in the region. Objective one of the study was achieved through profiling of each project (Tables $1-14$ ) and Objective two was achieved through testing of association among variables (Table 15).

\section{Acknowledgements}

The South African Department of Rural Development and Land Reform is acknowledged for funding. The following Departments/Research Institutes / Local Municipalities are acknowledged: Limpopo Department of Agriculture; Waterberg District; Waterberg Local Municipalities; Waterberg Local Farmers; Waterberg Local Economic Development Agencies and the Agricultural Research Council.

\section{References}

Anley, Y., Bogale, A., \& Haile-Gabrile, A. (2007). Adoption decision and use intensity of soil and water conservation measures by smallholder subsistence farmers in Dedo district, western Ethiopia. Land Degradation and Development, 18, 289-302. http://dx.doi.org/10.1002/ldr.775

Carstens, J., \& Van der Walt, M. (2013). Agripark Situational Analysis Report. Agricultural Research Council Institute for Soil, Climate and Water, Pretoria.

FAO. (Food and Agricultural Organisation). (2012). The State of Food and Agriculture - An FAO Perspective. Rome.

Harvey, M. (2012). The efficiency with farm inputs - a recipe for productivity report. Rabobank, 2012.

Maddison, D. (2007). The Perception of and Adaptation to Climate Change in Africa. Policy Research Working Paper 4305. World Bank, Washington DC.

Makhura, M. N., \& Mokoena, M. (2003). Market access for small-scale farmers in South Africa. In L. Nieuwoudt \& J. Groenewald (Eds.), The Challenge of Change: Agriculture Land and the South African Economy. Scottsville: University of Natal Press.

Makhura, M. T. (2001). Overcoming transaction costs barriers to market participation of smallholder farmers in Limpopo Province of South Africa. Published PhD Thesis, University of Pretoria.

Maponya, P., \& Moja, S. (2012). Asset portfolios and food accessibility in Sekhukhune District, Limpopo Province. Journal of Agricultural Science, 4(12), 144-153.

Mathye, M. M., Makhura, M. T., \& Kirsten, J. F. (2000). Transaction costs in the marketing of bananas: explaining market participation of smallholders in the Northern Province. Paper presented at the 38th annual AEASA conference. Sun City 27-29, September 2000.

Molla-Bauza M. B., Martinez-Carrasco M. L., Poveda, A. M., \& Perez, M. R. (2005). Determination of the surplus that consumers are willing to pay for an organic wine. Spanish Journal of Agricultural Research, 3(1), 43-51.

Osci-Bimpch, G. (2013). Building resiliency for upcoming challenges: The need to restore confidence in smallholder farmers. Agriculture Research report (Ghana). Retrieved 15 February, 2014, from http://gh.sendwestafrica.org

StatsSA. (Statistics South Africa). (2011). Community survey 2007, Statistics South Africa, Pretoria.

UNESCO. (United Nations Educational, Scientific and Cultural Organisation). (1995). Retrieved 15 December, 2013, from http://www.unesco.org

Van Rooyen, C. J., Vink, N., \& Christodoulou, N. T. (1987). Access to the agricultural market for small farmers in Southern Africa: The farmer support programme. Development Southern Africa, 4(2), $207-223$. http://dx.doi.org/10.1080/03768358708439312

Waterberg District Municipality. (WDM). (2013). The status of agriculture in Waterberg District, Limpopo Province.

\section{Copyrights}

Copyright for this article is retained by the author(s), with first publication rights granted to the journal.

This is an open-access article distributed under the terms and conditions of the Creative Commons Attribution license (http://creativecommons.org/licenses/by/3.0/). 